\title{
Democracy, the Constitution and Municipal REORGANIZATION: BOROUGH OF EAST YORK V. ATTORNEY GENERAL OF ONTARIO
}

\author{
JOHN P. MCEVOY
}

\section{INTRODUCTION}

Governments of all political stripes in Canada are, to varying degrees, committed to the two populist slogans of our times, "debt reduction" and "participatory democracy." To effect debt reduction, balanced budget legislation has been enacted in some jurisdictions so that over a given fiscal period (for example, one or four years) expenditures must not exceed revenues. ${ }^{2}$ To achieve this, strategies have been adopted to promote fiscal efficiencies by privatizing government services, reducing or eliminating government-funded programs, and downsizing public sector employment.

To further the goal of "participatory democracy," greater public participation is promoted through more frequent public consultations and occasions for various and discrete levels of expression of views on matters of public concern. One of the most obvious examples of such public involvement has been in relation to the continuing efforts at constitutional renewal - consultations which at times have tested the fortitude of the Canadian public.

Unfortunately, "debt reduction" and "participatory democracy" are not necessarily consistent goals. Democracy is inherently expensive. To reduce government costs, it is often found convenient to achieve efficiencies by reducing the opportunities for effective public participation in government. Government-directed municipal amalgamation illustrates the conundrum of a measure instituted to gain efficiencies by reducing the numbers of political decision-makers, and their related staff, but at the same time reducing the closeness of government to the people. The Ontario government's unilateral decision to amalgamate the six cities of Metro-Toronto into one mega-city resulted in an unsuccessful court challenge, Borough of East York v. Attorney General of Ontario, ${ }^{3}$ based on an alleged breach of Charter rights and the principles of democratic government. The lack of success of the challenge is a lesson to all Canadians, and to municipal politicians in particular, on the tenuous nature of municipal government in our constitutional order.

Faculty of Law, University of New Brunswick (McEvoy@unb.ca).

Also expressed as "government closer to the people."

For example: Balanced Budget and Debt Retirement Act, S.A. 1995, c. B-0.5, s. 2 (one year) and Balanced Budget Act, S.N.B. 1993, c. B-0.1, s. 1 ("Subsequent fiscal period" means four years) title as am. by S.N.B. 1995, c. 23.

3 [1997] O.J. No. 4100 (C.A.) (QL) [hereinafter East York (C.A.)], aff g [1997] O.J. No. 3064 (Gen. Div.) (QL) [hereinafter East York (Gen. Div.)]. 


\section{FACTS AND ISSUES RAISED}

In December 1996, the government of Ontario announced its intention to amalgamate the six cities of Metro-Toronto - Etobicoke, Scarborough, Toronto, York, East York and North York - into one city with a single mayor, council and civic administration. The announcement was greeted with some measure of surprise by the affected local politicians and citizenry as the proposed amalgamation had not been specifically included in the platform on which the government had been elected. Surprise was not complete, however, as the matter of reform of the organizational structure of MetroToronto had been a subject of continuing study and discussion though the exact nature of the eventual reform was unknown. ${ }^{4}$ Just days before the government's announcement, the mayors of the six affected municipalities issued a report recommending a reform which was the very opposite of that intended by the government. Rather than amalgamation, the mayors' report recommended abolition of the common structure of metro-government in favour of devolution of responsibility and service delivery to the separate municipalities. ${ }^{5}$

Bill 103, which became the City of Toronto Act, 1997, ${ }^{6}$ received first reading in the Ontario Legislature on 17 December 1996 and Royal Assent on 21 April 1997. Its passage through the Legislature was anything but quiet as the opposition parties attempted to delay its adoption by submitting for debate literally thousands of computer-generated amendments, a log-jam finally broken by a Speaker's ruling disallowing such amendments. ${ }^{7}$ Public reaction to the Bill was also clearly negative; at least as reflected in a March 1996 plebiscite, held simultaneously in all six municipalities, in which the proposed amalgamation scheme was rejected by an overall three to one vote. ${ }^{8}$

For example: Ontario, Report of the Royal Commission on Metropolitan Toronto (Toronto: Queen's Printer, 1965) (Commissioner: H.C. Goldenberg); Ontario, Royal Commission on Metropolitan Toronto, Report: Metropolitan Toronto: A Framework for the Future, vol. 1 (Toronto: Queen's Printer, 1977) (Commissioner: J.P. Robarts); Ontario, Royal Commission on Metropolitan Toronto, Report: Detailed Findings and Recommendations, vol. 2 (Toronto: Queen's Printer, 1977) (Commissioner: J.P. Robarts).

s Change for the Better: A Framework for Restructuring Local Government (the so-called "Six Mayors Report"), cited in East York (Gen. Div.), supra note 3 at para. 7.

S.O. 1997, c. 2.

7 W. McCann, "Ontario Asks Speaker to End 'Frivolous' Filibuster" Canadian Press (6 April 1997) (QL Database CP97):

The opposition New Democrats and Liberals have been trying to thwart passage of Bill 103 and found a novel loophole in the legislative process last week, when they began introducing close to 13,000 versions of a single amendment.

At a rate of one amendment every three minutes, rotating speakers have been asking members of the legislature to vote street-by-street on a 30-day notice period before the legislation could be introduced.

The amendment would also allow for three weeks of public hearing if at least 10 residents of a particular street requested it.

The question posed in the plebiscite was: "Are you in favour of eliminating [name of municipality] and all other existing municipalities in Metropolitan Toronto and amalgamating them into a megacity?" The percentage vote in each of the six municipalities was reported as follows:

$\begin{array}{lll} & \text { Yes } & \text { No } \\ \text { Toronto } & 26.5 \% & 73.5 \% \\ \text { York } & 34.7 \% & 65.3 \%\end{array}$


The amalgamation and creation of the new Toronto is, per the Act, effective on 1 January 1998, and elections were held on 10 November 1997 to select the mayor and 56 councillors representing the 28 wards into which the new city is divided. The transitional provisions, contained in Part III of the Act, came into effect upon Royal Assent in April 1997 and include two temporary bodies appointed by the Lieutenant Governor in Council. The first is a financial advisory board with powers to act, for all practical purposes, as financial overseer of the elected councils of the six municipalities. The existing councils are expressly forbidden by the $A c t^{9}$ from exercising a number of usual municipal powers during the transition period, unless exercised in conformity with guidelines established by the financial advisory board. The matters prohibited include: conveying or purchasing an interest in real property with a value in excess of $\$ 100,000$; transferring money between reserve funds or changing the purpose of any reserve fund; undertaking any contractual obligation for a period extending beyond the transition period; and appointing, hiring, or promoting an employee. In addition, the municipal operating and capital budgets, expenditures for such items, and quarterly comparative reports are required to be submitted by each municipality for the consideration of the board. If the board expresses concern regarding any of the information submitted, the municipality is required to change or confirm the budget as submitted. ${ }^{10}$ The municipal council cannot ignore the financial advisory board and is placed under a duty to fully cooperate with the board and its staff."

$\begin{array}{lll}\text { East York } & 18.5 \% & 81.5 \% \\ \text { North York } & 20.6 \% & 79.4 \% \\ \text { Etobicoke } & 30.3 \% & 69.7 \% \\ \text { Scarborough } & 21.9 \% & 78.1 \% \\ & & \\ \text { Votes cast } & 123,488 & 381,657 \\ & 24.4 \% & 75.6 \%\end{array}$

M. Campbell et al., "Metro voters reject amalgamation" Globe and Mail (4 March 1997) A1, A10. Supra note 6 at s. 14:

14(1) During the transitional period, an old council or a local board of an old municipality shall not do an act ... unless

(a) the act is done in accordance with a guideline... or

(b) the old council's or local board's budget specifically provides for the act, has been submitted to the financial advisory board and considered by it...

(2) Subsection (1) applies to the following acts:

1. Conveying an interest in property whose original purchase price or actual current value exceeds $\$ 100,000$.

2. Purchasing an interest in property for a price that exceeds $\$ 100,000$.

3. Transferring money between or among reserves or reserve funds, or changing the purpose or designation of a reserve or reserve fund.

4. Entering into a contract or incurring a financial liability or obligation that extends beyond the end of the transitional year.

5. Making or agreeing to make a payment in connection with the ending of an employment relationship, except in accordance with a contract or collective agreement entered into before the day this section comes into force.

6. Appointing a person to a position, hiring a new employee or promoting an existing employee. 
The second temporary body created by the Act to facilitate the amalgamation is the transition team which, like the financial advisory board, is appointed by the Lieutenant Governor in Council ${ }^{12}$ with specific powers superseding those of the six separate municipal councils. Generally, the duties of the transition team pertain to the holding of public consultations and making of recommendations to either the Minister or the new council of the amalgamated city on issues arising in relation to the amalgamation. ${ }^{13}$ More significantly, it is also conferred responsibility to "establish the key elements of the new city's organizational structure and hire ... the municipal officers required by statute and any other employees of executive rank" and to propose the first operating and capital budget of the amalgamated city for the consideration of the new council..$^{14}$

As with the financial advisory board, the Act empowered the transitional team to require the six separate councils to submit reports and furnish information and documents in relation to such matters as the identification of assets and liabilities, employee particulars such as terms of employment and benefits, and subsidiary entities to which appointments were made by each council or which received money from each council..$^{15}$

Five of the six municipalities (the exception being North York), four public interest groups, and 125 individuals challenged the constitutional validity of the Act in three separate applications which were heard and decided together by Borins J. in the Ontario Court of Justice, General Division. ${ }^{16}$ An appeal to the Ontario Court of Appeal was taken by the public interest groups and the concerned citizens, but not the affected municipalities. ${ }^{17}$ At the initial stage of proceedings, the applicants argued that the $A c t$ (i) was ultra vires the exclusive jurisdiction of the Legislature in relation to "Municipal Institutions in the Province" under s. 92(8) of the Constitution Act, $1867^{18}$ and (ii) infringed freedom of expression, freedom of association, the right to liberty, the right to be secure against unreasonable seizure, and the right to equality as guaranteed by the Canadian Charter of Rights and Freedoms, ss. 2(b), 2(d), 7, 8 and 15(1) respectively.

On appeal to the Court of Appeal, the grounds were somewhat narrowed.

\section{Ontario Court of Justice: Decision of Borins J.}

Borins J. found no merit in the challenge under the Constitution Act, 1867, s. 92(8), the exclusive provincial jurisdiction in relation to "Municipal Institutions in the Province." Citing well-established precedent, he reiterated the principles of Canadian constitutional law that a legislature may, at will, delegate and withdraw authority conferred on its delegates and, pursuant to its exclusive legislative jurisdiction in 
relation to "Municipal Institutions in the Province," may create municipalities in both a local government and territorial sense as well as withdraw and redistribute the authority delegated through such means as municipal amalgamation. ${ }^{19}$ In a summary fashion, Borins $\mathrm{J}$. accepted four principles as characterizing the nature of municipal institutions in Canada: (i) municipal institutions enjoy no constitutional status; (ii) municipal institutions are creatures of the legislature and their existence depends on provincial legislation; (iii) municipal institutions and powers have no autonomy independent of the legislature and are subject to the will of the legislature; and (iv) municipal institutions enjoy only such powers as are delegated by the legislature. ${ }^{20}$ The essential argument on behalf of the applicants did not, however, depend on revisiting these established constitutional principles. Rather, the applicants argued that the lack of consultation by the provincial government before proceeding with the amalgamation scheme and the creation of the two unelected transitional bodies, the financial advisory board and the transition team, ${ }^{21}$ with authority in relation to the elected municipal councils violated a constitutional convention respecting the inherent autonomous and democratic nature of local government. In other words, the argument advanced on behalf of the applicants was that when a legislature creates a municipal government with local law-making authority over its defined territory, there is a constitutional convention that the legislature will respect the autonomous and democratic nature of that local government by consulting with or obtaining the consent of the municipality before enacting any restructuring of the municipality. This novel argument did not succeed for two reasons. First, no evidence or authority was submitted in support of the existence of such a convention and, second, even if such a convention is accepted, conventions are political, not legal, in nature and any remedy is to be found in the political rather than the curial forum. ${ }^{22}$ To augment the lack of merit of any precondition of consultation or consent, Borins J. noted that "there is no constitutional obligation on the state to consult those specifically affected by legislation, or any other persons, before it is enacted." 23

East York (Gen. Div.), supra note 3 at paras. 13-14, citing Attorney General for Ontario v. Attorney General for the Dominion, [1896] A.C. 348 at 364 (H.L.); Re Gray (1918), 57 S.C.R. 150.

$20 \quad$ East York (Gen. Div.), ibid. at para. 14.

21 Borins J. characterized the sections of the Act pertaining to the financial advisory board and the transition team as "necessarily incidental" to the purpose of the Act, which is the restructuring of Metro-Toronto (ibid. at para. 17). The use of the necessarily incidental doctrine in this context is inappropriate as Borins $\mathrm{J}$. found that both the pith and substance of the legislation in general and of these sections in particular were within the scope of "Municipal Institutions in the Province." Recourse to the necessarily incidental doctrine would only have been necessary had Borins $J$. characterized the "matter" of the sections dealing with the financial advisory board and the transition team as falling within one of the classes of subjects of exclusive federal legislative jurisdiction under the Constitution Act, 1867, supra note 18, s. 91. With that characterization, the sections could have been held intra vires as necessary to the efficacy of the otherwise valid purpose of the legislation.

22 East York (Gen. Div.), ibid. at para. 15, citing Re Resolution to Amend the Constitution of Canada, [1981] S.C.R. 753 at $877 \mathrm{ff}$.

23 East York (Gen. Div.), ibid, citing Native Women's Association of Canada v. Canada, [1994] 3 S.C.R. 627. 
Arguments based on alleged violations of the Canadian Charter of Rights and Freedoms were also dismissed. Assuming that voting is an expressive activity within the scope of s. 2(b) of the Charter, ${ }^{24}$ Borins $\mathrm{J}$. found that freedom of expression is not infringed by either the purpose or effects of the Act. Considered as an expressive activity, Borins $\mathrm{J}$. held the mere act of voting and the expression of ideas involved in communication between a resident/elector and a municipal councillor does not change by the fact of a municipal amalgamation. While he recognized that the ratio of electors to municipal councillors would change, he found no constitutional right to any pre-set ratio of electors to councillors. ${ }^{25}$ Borins $\mathrm{J}$. also held that the argued potential for the amalgamation to result in the creation of municipal political parties had not, on the evidence, been shown to result in an infringement or denial of the freedom of expression of any elector. The challenge premised on freedom of association, s. 2(d) of the Charter, centred on the positive and negative aspects of association. Both positive and negative aspects of the freedom were reflected in the will of the affected residents, as evidenced by the plebiscite results in each of the municipalities, to remain associated within the six separate municipalities (the positive aspect of freedom to associate), and not to be associated with each other in the amalgamated city (the negative aspect of freedom from compelled association). Borins $J$. rejected this argument for two reasons. First, the right to freedom of association is an individual rather than a collective or majority right ${ }^{26}$ and, second, such an interpretation of the right would result in an unintended limitation on the exclusive jurisdiction of provincial legislatures in relation to "Municipal Institutions" under the Constitution Act, 1867. ${ }^{27}$

East York (Gen. Div.), ibid. at para. 18, citing Haig v. Canada, [1993] 2 S.C.R. 995 at 1031.

East York (Gen. Div.), ibid. at para. 20, citing Re Electoral Boundaries Commission Act (Saskatchewan), [1991] 2 S.C.R. 158 at 184. The applicants' argument on this point seems to have been based on the constitutional recognition of an implicit municipal electoral quotient perhaps analogous to the express provisions applicable to the distribution of seats in the House of Commons. See: Constitution Act, 1867, supra note 18, s. 51.

The Act provides for a council consisting of a mayor and 56 councillors to replace the existing structure consisting of 112 local representatives. This includes the Metro Council of the six mayors and 34 councillors, and six municipal councils consisting of the six mayors and 72 councillors viz. East York, mayor and 8 councillors; Etobicoke, mayor and 12 councillors; North York, mayor and 14 councillors; Scarborough, mayor and 14 councillors; Toronto, mayor and 16 councillors; and York, mayor and 8 councillors (Council size statistics courtesy of the Mayor's Office of each municipality).

In the absence of ready access to the municipal voters list statistics, a crude approximation of the ratio of voters to elected council representatives can be calculated by using Statistics Canada, Census of Population, 1996 figures (found at the Toronto website, www.city.toronto.on.ca) for each of the six municipalities and dividing by the size of council (mayor and councillors). The results indicate that the number of residents per elected representative are as follows: East York, 11,980; Etobicoke, 25,286; North York, 39,310; Scarborough, 37,264; Toronto, 38,455; and York, 16,282. After amalgamation, the ratio of residents per elected official is approximately 41,848 to 1 which is slightly higher than that existing pre-amalagamation in North York, Scarborough, and Toronto. It is significantly higher than the ratio in the other three municipalities.

East York (Gen. Div.), ibid. at para. 22, citing Re Public Service Employee Relations Act, [1987] I S.C.R. 313 at 398-400.

As expressed by Borins J.: "Taken to its logical conclusion, if s. 2(d) applied to the formation of municipalities, it would enable citizens to determine their own municipal boundaries, contrary to the power of the province to do so under s. 92(8)" (ibid. para. 22). 
Again, Borins J. concluded that neither the purpose nor the effect of the Act infringed or denied freedom of association.

The three remaining Charter grounds were given brief attention by Borins J. First, the alleged infringement of the right to liberty, per s. 7, was presented on behalf of the applicants as grounded in the lack of consultation and in the imposition of the unelected financial advisory board and transition team upon the elected municipal councils and the affected citizens/residents. Having already found no right to consultation and having determined in favour of the constitutional validity of the creation of the two transitional bodies, Borins $\mathrm{J}$. found that no liberty interest of the applicants had been demonstrated to have been affected and that, in any event, assuming deprivation of such an interest, the applicants had failed to establish the necessary breach of "the principles of fundamental justice."28 Second, the alleged breach of the Charter right to be secure against unreasonable seizure was rejected as Borins $\mathrm{J}$. held that no seizure within the meaning of s. 8 was effected by the amalgamation legislation. Rather, the assets of the six municipal corporations were, upon amalgamation and the disappearance of the legal existence of the separate municipalities, simply transferred to the newly created municipal corporation of Toronto. Third, responding to the alleged breach of equality rights per s. 15 of the Charter, Borins J. held that the applicants had failed to prove that members of the identified groups of "immigrants, visible minorities, single mothers, persons who do not speak English or French, and persons living below the poverty line" would be disadvantaged by any provision of the amalgamation legislation. ${ }^{29}$ The argument of the applicants on this point, though not expressed by Borins J., seems to have been grounded in the demographic considerations arising from the newly established wards which crossed natural and artificial neighbourhoods and communities and would potentially negatively affect the interests of distinctive communities and groups. Finally, it should be noted that Borins J. also complemented the substantive reasons for his decision in relation to the municipal applicants by noting that neither s. 7 nor s. 15 rights are, per established jurisprudence, exercisable by a corporation and, in this matter, by the applicant municipal corporations. ${ }^{30}$

\section{THE COURT OF APPEAL}

The appeal to the Ontario Court of Appeal was equally unsuccessful. In the brief reasons for decision of Abella J.A., concurred in by Rosenberg and Moldaver JJ.A., the Court summarily rejected appeal arguments based on alleged infringements of freedom of expression and the right to equality, and on the purported limit on provincial legislative jurisdiction in relation to municipal institutions.

The freedom of expression argument repeated the focus on the increase in the ratio between voters and elected representatives and the argued resulting diminution of access by voters, particularly disadvantaged persons, to their representatives in the

29 East York (Gen. Div.), ibid. at para. 29.

30 Ibid. at para. 25, citing Irwin Toy Lıd. v. Québec, [1989] 1 S.C.R. 927; R. v. Paul Madger Furs (1989), 69 O.R. 172 (C.A.). 
amalgamated city. In rejecting this argument, Abella J.A. quoted the statement of McLachlin J. in Reference Re Electoral Boundaries Commission Act (Saskatchewan) ${ }^{31}$ that the interest protected is not "equality of voting power per se, but the right to 'effective representation'"'32 and noted the lack of reliable evidence before the court that "the particular ratios in this case fall below constitutional standards." ${ }^{33}$ The equality rights argument, per s. 15(1) of the Charter, was rejected because whether considered variously on the basis of "personal characteristics," "the stereotypical application of presumed group or personal characteristics" or "membership in an identifiable group,"34 the amalgamation legislation did not make a prohibited or suspect distinction. The Act, as Abella J.A. emphasized, merely restructured municipal government within the boundaries of the existing municipality of Metro-Toronto and was not based on any distinction involving Charter protected characteristics. The argument that the amalgamation would have a discriminatory impact on disadvantaged groups was characterized by Abella J.A. as a "theoretical concern" for which, as Borins J. had also held, no sufficient evidence had been adduced. ${ }^{35}$

Finally, Abella J.A. found no merit in the argued consitutional convention, recast before the Court of Appeal as an implicit constitutional norm, that provincial legislative jurisdiction in relation to "Municipal Institutions" cannot be exercised without the consent of the affected municipality. Again, the lack of evidence to support the existence of either such a convention or norm undermined the argument. Referring to the "expressions of public disapproval" regarding the amalgamation, Abella J.A. properly assigned the argued convention or norm to the political arena: "courts can only provide remedies for the public's grievances if those grievances violate legal, as opposed to political proprieties. What is politically controversial is not necessarily constitutionally impermissible."36

\section{COMMENTARY}

In East York, opponents of amalgamation marshalled the legal arguments available to them but could not prevail against the fundamental weakness of their own case the complete lack of constitutional recognition of the status of municipal corporations as a local constituent unit of democratic government. The Constitution recognizes only the federal and provincial governments and, had the Charlottetown Accord been adopted, would have recognized "the governments of the Aboriginal peoples of Canada as constituting one of the three orders of government in Canada."37 Almost as a matter of tradition, Canadian and American courts have described the nature of a municipal

East York (C.A.), supra note 3 at para. 6, citing Re Electoral Boundaries Commission Act (Saskatchewan), supra note 25 at 183.

East York (C.A.), ibid. at para. 6.

Ibid. at para. 5.

Ibid. at para. 9, citing Egan and Nesbit v. Canada, [1995] 2 S.C.R. 513 at 584, Cory J.; Miron v. Trudel, [1995] 2 S.C.R. 418 at 485, McLachlin J.; and Egan, ibid. at 552-53, L'Heureux-Dubé J. East York (C.A.), ibid. at para. 10.

Ibid. at para. 12.

Constitution Act, 1982, being Schedule B to the Canada Act 1982 (U.K.) 1982, c. 11, s. 35.1(2)

as proposed by the Charlottetown Accord (Draft Legal Text, 9 October 1992) s. 29. 
corporation in the terms given by Chief Justice Marshall of the United States Supreme Court in 1819:

A corporation is an artificial being, invisible, intangible, and existing only in contemplation of law. Being the mere creature of the law, it possesses only those properties which the charter of its creation confers upon it, either expressly or as incidental to its very existence. ${ }^{38}$

In Ladore v. Bennett ${ }^{39}$ which arose in relation to the amalgamation which created the city of Windsor, Ontario, the Judicial Committee summarized provincial jurisdiction in most expansive terms:

Sovereign within its constitutional powers, the Province is charged with the local government of its inhabitants by means of municipal institutions.... If corporation $A$ or $B$ or $C$ is unable to function satisfactorily it would appear to be elementary that the Legislature must have power to provide that the functions of one or all should be transferred to some other body or corporation. For this purpose, as the corporation could be created by the Province, so it could be dissolved, and a new corporation created as a municipal institution to perform the duties performed by the old.... Amalgamation of municipalities for the purposes of more effective administration, whether for financial or other reasons, is a common incident of local government. ${ }^{20}$

There never was any real question of the jurisdiction of the Ontario legislature to order the amalgamation of the six Metro-Toronto municipalities. An earlier amalgamation, in 1967, had created those same six municipalities through concurrent amalgamations involving the original thirteen municipalities federated together to create the Metro system in $1953 .^{41}$ The substantive issue before the court was the argued democratic principle encapsulated in the pretended constitutional convention that, once constituted, municipal government would not be altered without the consent of the affected residents, or at least without consultation. Lofty in defence of democracy at the local

Dartmouth College v. Woodward, 4 Wheat. 518 at 636 (1819). Quoted in J.F. Dillon, Municipal Corporations, 5th ed., vol. 1 (Boston: Little, Brown and Company, 1911) at 57-58 and in Board of Public School Trustees Sections 16 and 18, Townships of Murray and Brighton v. United Counties of Northumberland \& Durham, [1939] O.W.N. 565 at 566 (H.C.J.), rev'd on other grounds [1940] 2 D.L.R. 28 (Ont. C.A.), aff'd [1941] S.C.R. 204. Cited in I.M. Rogers, The Law of Canadian Municipal Corporations, 2d ed. (Toronto: Carswell, 1971) at 1. Consider also The Board of County Commissioners of the County of Laramie v. The Board of the County Commissioners of the County of Albany, 92 U.S. 307 at 308 (1875):

Counties, cities and towns are municipal corporations, created by the authority of the

Legislature; and they derive all their powers from the source of their creation.... Unless the

Constitution otherwise provides, the Legislature still has authority to amend the charter of such a corporation, enlarge or diminish its powers, extend or limit its boundaries, divide the same into two or more, consolidate two or more into one, overrule its actions whenever it is deemed unwise, impolitic or unjust, and even abolish the municipality altogether, in the legislative discretion.

Ibid. at 480-81. See also City of Mississauga v. Regional Municipality of Peel, [1979] 2 S.C.R. 244 at 252, Laskin C.J.C. 
level, the argument in favour of such a convention overshot its mark by a wide margin. In Re Resolution to Amend the Constitution, ${ }^{42}$ the Supreme Court majority identified three questions requisite to the existence of a constitutional convention: "first, what are the precedents; secondly, did the actors in the precedents believe that they were bound by a rule; and thirdly, is there a reason for the rule? A single precedent with a good reason may be enough to establish the rule." ${ }^{13}$

Notwithstanding the admittedly good reason for the rule, respect for local democratic autonomy, the applicants in East York failed because of the paucity of precedents to support the existence of such a rule and the failure to demonstrate any instance in which political actors considered themselves bound by the supposed rule. The fundamental weakness of their contention may have been merely a factor of time, that they were forced to their argument before the precedents and sense of political obligation have matured. This is not to suggest that such precedents presently exist; rather, that the present populist political climate may, in the longer term, create the necessary precedents and sense of political obligation to give substance to the argued convention. The additional problem faced by the applicants in mounting an effective convention argument was that the political nature of conventions and of the remedies for their breach will not be eased by the passing of time without some fundamental readjustment of our constitutional order by the Supreme Court or by constitutional amendment.

The Charter arguments advanced by the applicants were equally misplaced and rightly rejected, however, the applicants did use all the tools available to them. That the Charter applies to a municipal corporation in the exercise of its delegated governmental functions admits of no doubt. Municipal authority to adopt and enforce by-laws marks municipal governments as exercising coercive state power to regulate, control and prohibit public and private conduct and, therefore, to come within the meaning of "legislature and government of each province" in the application section of the Charter, s. 32.4

The critical element in East York, however, is not the use of the Charter by persons to defend against or challenge the validity of municipal by-laws because of some infringement or denial of a Charter right or freedom. Rather, the critical element is the attempted use of the Charter to defend the municipality, its government and residents, against the all-pervasive power of the provincial legislature to reorganize their local government structure regardless of their democratically expressed wishes. The infringements of Charter rights and freedoms alleged by the applicants were not the rights and freedoms of the municipalities as corporations or as local governments, but

$42 \quad[1981] 1$ S.C.R. 753.

43 Ibid. at 888, citing Sir Ivor Jennings, The Law and the Constitution, 5th ed. (London: University of London Press, 1959) at 136.

4 Peterborough v. Ramsden, [1993] 2 S.C.R. 1084. See also P.W. Hogg, Constitutional Law of Canada (Student Edition) (Toronto: Carswell, 1997) at 669; J.P. McEvoy, "The Charter and Municipal Law in New Brunswick" (1992) 126 N.B.R. (2d) 1; and F. Hoehn, Municipalities and Canadian Law: Defining the Authority of Local Governments (Saskatoon: Purich Publishing, 1996) at $324 \mathrm{ff}$. 
were directed generally at the rights and freedoms of the residents of the six municipalities to expression, association, liberty, and equality. ${ }^{45}$ All of these allegations were unsuccessful and for one very basic reason. They were too speculative and were not supported by the evidence before the court.

The very multiplicity of alleged violations of the Charter seemed grounded in mere hope, hope that one would stick, rather than at developing and presenting a reasoned and convincing argument. For example, the argument that amalgamation has the potential to restrict freedom of expression because of the possibility that municipal political parties may arise to act at the larger municipal level, an argument perhaps premised on economies of scale, was supported by logical inference rather than evidence. Doubtless it is less expensive to convey or express one's views on civic matters in smaller municipalities than in larger urban centres (by means of mailouts or issue advertising) and it is more economically efficient to organize into parties or collectives to express common views than to do so individually at one's own expense. Yet, is freedom of expression in relation to municipal matters less in Montreal, where municipal political parties exist, than in Toronto and other centres where they do not? No such evidence was presented to the court.

The argument invoking freedom of association, which was not pursued before the Court of Appeal, is more problematic. Borins $\mathrm{J}$. dismissed this argument at the first stage; that is, that the applicants failed to satisfy the evidential burden upon them to demonstrate an infringement of the right. In support of this holding, Borins J. quoted La Forest $\mathrm{J}$. in Lavigne ${ }^{46}$ stating that, considered in a realistic context, freedom of association could not have been intended to protect the individual from association with the state and government. While Borins J. may well be correct in his analysis of the freedom of association issue, it seems that a majority of the justices of the Supreme Court of Canada in Lovigne having accepted a negative aspect to freedom of association (freedom not to associate), it may have been preferable to have decided the matter at the s. 1 stage of analysis with the burden on the respondent government. The justification analysis under $\mathbf{s}$. 1 would have been rather straightforward as the court could easily have determined that the associational interests raised by the applicants are far from the core of values protected by freedom of association and, therefore, demand a more modest standard of justification for infringement. ${ }^{47}$ At the same time, the nature of the forced association is of such an indirect or tangential nature as to be considered a minimal impairment.

East York (Gen. Div.), supra note 3 at para. 27. The argument based on the right to be secure against unreasonable seizure did focus on the collective property of each of the municipalities but, as found by Borins J., involved in reality not a seizure but rather a transfer to the successor institution. or the advancement of common causes" per Dickson C.J.C. in Re Public Service Employee Relations Act, [1987] 1 S.C.R. 313 at 334. Consider the analysis of Miller J. in Beck v. City of Edmonton, [1994] 1 W.W.R. 248 regarding a municipal by-law requiring taxi drivers to be in a contractual relationship with a broker. 
The other Charter arguments of the applicants were dismissed for lack of an evidential basis to establish infringement and need no longer concern us. It bears repeating that in East York the opponents of amalgamation used the tools available to them. The true lesson must surely be that the Charter is incomplete. It is not a panacea for all of the complaints of the citizen against the actions of government.

Constitutional litigation is often a strategic tool of last resort. Assuming that negotiations, if any, have proved futile, an aggrieved party may resort to other avenues of redress. The two most favoured fora are the media and the courts (and other tribunals) and are often used in tandem. Publicity associated with commencing legal or administrative proceedings may assert moral and public pressure on the respondent to adopt a more conciliatory attitude and provide an opportunity to achieve an acceptable resolution of the matter in dispute. Whether the matter is of a public or private law nature, the focus of the dispute may be a difference in perception of the respective substantive rights and obligations of the parties; in which event, resolution may be achieved through the doctrines of statutory interpretation.

Alternatively, success may be defined by one party as achieving a delay in the implementation of a decision; in this situation, the focus of analysis may be on procedural defects attendant on the principles of administrative law. As a second alternative, the very validity of the applicable law itself may be placed in issue and the matter argued as a question of constitutional law. It is this latter approach to dispute resolution that we find in East York. That does not mean, however, that the other means of dispute resolution did not contribute to the ultimate effort.

The marshalling of public opinion exerted its influence on the development of the government's final amalgamation legislation. As noted above, ${ }^{48}$ voters in the separate but contemporaneous municipal plebiscites on the question of amalgamation voted overwhelming against the scheme. The influence of even an overwhelming demonstration of popular opposition failed to sway an ideologically committed government.

In Ontario, the government's commitment to structural changes reflective of financial efficiencies is not limited to presumed savings in municipal institutions but rather extends to a plethora of government services and institutions. To have responded directly to the manifestation of popular will would have placed the government at risk of mounting public expressions of disapproval in other areas of its program; for example, the reduction in the number of hospitals ${ }^{49}$ and school boards. ${ }^{50}$ Accordingly, it was necessary for the government to interpret the results of the plebiscites not as a repudiation of the amalgamation itself but rather as concern with specific aspects of the scheme, and to address those concerns. This the government did by introducing a series of amendments to Bill 103 following completion of hearings on the Bill before a

Supra note 8 and accompanying text.

Savings and Restructuring Act, 1996, S.O. 1996, c. 1, Schedule F creating the Health Services Restructuring Commission.

Fewer School Boards Act, S.O. 1997, c. 3. 
standing committee of the Legislature. ${ }^{51}$ These amendments included an assurance of property tax stability under the new municipal budget and the strengthening of community councils and neighbourhood committees. Intransigence by the government in its commitment to amalgamation meant that the expression of public will alone could not achieve a result acceptable to the opponents of amalgamation; hence, recourse to the courts.

Following introduction of the amalgamation Bill, its opponents achieved an early success in challenging the validity of one element of the amalgamation project, the initial embodiment of the transition team. As introduced at first reading, Bill 103 would have created a board of trustees appointed by the Lieutenant Governor in Council to "monitor the actions" of the municipal councils during the transition period and included among its powers the authority to approve or not municipal operating and capital budgets. ${ }^{52}$ It will be recalled that Bill 103 was given first reading in the Legislature on 17 December 1996 with third reading and Royal Assent completed four months later on 21 April $1997 . .^{53}$ In the meantime, by Order in Council of 18 December 1996 (the day after first reading of Bill 103), the government had proceeded to put in place the transition structure by appointing the members of the board of trustees. The Ontario Court, General Division in Re Corporation of the City of Scarborough and Attorney General for Ontario ${ }^{54}$ declared these appointments (made before the coming into force of the constitutive legislation) invalid as premature and having been made without legislative or other authority. The government simply "jumped the gun" in a rush to set the amalgamation in motion and, no doubt inadvertently, ignored the constitutional principle enunciated by Lord Coke in the Case of Proclamations" that "the King hath no prerogative, but that which the law of the land allows him."."56

The rather rudimentary error made by Ontario officials in making appointments before the authority to do so is enacted is not an isolated event in the annals of municipal amalgamation. Similar errors occur elsewhere in Canada. In New Brunswick, an amalgamation scheme to create the new city of Miramichi was temporarily interrupted by a judicial determination that the Lieutenant Governor in Council lacks authority to appoint a transitional mayor and council for an amalgamated municipality. ${ }^{57}$ The authority of the government to order the amalgamation of the

Hansard Reporting Services, Hansard, 2 April 1997 "City of Toronto Act, 1996," Committee of the Whole House (Legislative Assembly of Ontario) (www.ontla.on.ca). The Minister introduced a series of 28 amendments.

52 Bill 103, An Act to replace the seven existing municipal governments of Metropolitan Toronto by incorporating a new municipality 10 be known as the City of Toronto, 1st Sess., 36th Leg., Ontario, 45 Elizabeth II, 1996 (1st reading 17 December 1996).

53

City of Toronto Act, 1996, S.O. 1997, c. 2.

(1997), 32 O.R. (3d) 526 (Gen. Div.). Brennan J. rejected an attempt to justify the appointments on the basis of an exercise of the royal prerogative as the appointments were inextricably linked to the function of the board of trustees under Bill 103 and because there was no indication on the record of any consideration being given to the royal prerogative at the time of the appointments. (1611), 77 E.R. 1352 (K.B.).

Ibid. at 1354.

Morrison and Mahoney v. New Brunswick (1994), 158 N.B.R. (2d) 161 (Q.B.), Riordon J. 
separate municipalities was not in doubt; the opening to the opponents of the amalgamation scheme was the attempt to facilitate the transition to one municipality by appointing the new mayor and council to serve during the four month period until the next municipal elections across the province. As a matter of statutory interpretation using first principles, the court held that the residual authority, contained in the Municipalities $A c t,{ }^{58}$ to "provide for all matters necessary or incidental to the ... amalgamation"s9 did not include authority to appoint a mayor and councillors. Given the statutory definition of the phrase "member of council" as "any person elected to a council," ${ }^{, 60}$ the Court of Queen's Bench justice held that the residual authority conferred by the statute in relation to amalgamations must be read consistently with the definitions under the $A c t$ and thus excluded an appointed mayor and council. The court also held that the residual authority to effect matters necessary or incidental to an amalgamation "must flow by necessary implication from other sections of the Act."

In effecting the amalgamation of Metro-Toronto, the Ontario government avoided another error which has arisen in relation to yet another basic principle of statutory interpretation. In New Brunswick, using its authority regarding amalgamations under the Municipalities Act, the government, by regulation, ordered the amalgamation of the city of Edmundston and three neighbouring municipalities. Opponents of this scheme found temporary comfort and success in the failure of government officials to appreciate the hierarchy of laws in our legal order. Regulations approved by the executive are of no force and effect if in conflict with the will of the Legislature as expressed in a statute. In relation to the city of Edmundston, the Legislature had in 1952 enacted special legislation to incorporate the former town as a city and included amongst its provisions a metes and bounds description of the city limits. ${ }^{62}$ On application of one of the neighbouring municipalities and a group of concerned citizens, the Court of Queen's Bench declared the regulation in issue of no force and effect as it was in conflict with the higher authority of the special statute. ${ }^{63}$ In response, the responsible Minister has announced that a Bill will be introduced in the legislature to overcome the judicial decision. ${ }^{64}$ The Ontario government avoided any such problem by, of necessity, introducing a special Bill to effect the amalgamation of Metro-Toronto. Such special legislation was necessary because of the statutory basis for the creation of the structure of Metro-Toronto in 1953. ${ }^{65}$

\section{Conclusion}

The Constitution recognizes only two levels of government in Canada, the federal and provincial. East York serves to remind municipal residents and politicians of that

R.S.N.B. 1973 , c. M-22, as am.

Ibid. at s. 19(f).

Ibid. at s. 1. The term "council" is defined as "the mayor and councillors."

Supra note 57 at 195 . In Alberta, the Municipal Government Act, S.A. 1994, c. M-26.1, s. 111 expressly authorizes the Lieutenant Governor in Council to "provide for an interim council."

The City of Edmundston Act, S.N.B. 1952, c. 49, s. 6.

Saint-Jacques c. Nouveau-Brunswick, [1997] A.N.B. no. 366, Angers J. (QL).

D. Gowan, "Province will force merger" Telegraph Journal (3 October 1997) A3.

Supra note 41. 
fact. As a creature of the provincial legislature, and exercising only delegated authority, municipal governments (and municipalities in a geographic sense) owe their continued existence to the will of the legislature - a not immutable will. Municipal structures of government, whether urban as in cities, towns or villages, or rural as in local service districts, are mere tools of the legislature for the more efficient administration of the province. In most provinces, county-based governments organized through county councils were long ago relegated to history because their usefulness as efficient units of local government on behalf of the legislature was no longer accepted.

Unlike the existence of the provinces, provincial legislative jurisdiction and provincial boundaries, ${ }^{66}$ municipal boundaries and powers, and the very existence of local government, are not constitutionally guaranteed. Ideological and other forces affect how municipal government is perceived by its principal, the legislature, and shape the ebb and flow of local authority. ${ }^{67}$

The exercise of delegated authority is never truly secure. The lesson of East York is not limited to municipal governments. The Ontario government has adopted a broad program of restructuring of service delivery and delegated self-governance. ${ }^{68} \mathrm{Hospital}$ boards in Ontario have already learned the lesson of East York. ${ }^{69}$ School boards in Ontario and other provinces have learned the same lesson. ${ }^{70}$ Individuals in the public as opposed to the civil service have long known the lesson, sometimes phrased in this context as "who lives by the order-in-council, dies by the order-in-council." The lesson itself is aptly captured in the well-worn adage that "no one is safe while the legislature sits.""1

Constitution Act, 1867, supra note 18, s. 92; Constitution Act, 1982, supra note 37, s. 43(a).

In the early 1980s, the Thatcher government in the United Kingdom, reacting in part to the Labour Party control of local councils, created separate urban development corporations controlled by government appointed boards to assume responsibility for local planning from local councils. One of the first such corporations was established to develop the London docklands. See J.A. Chandler, Local Government Today, 2d ed. (Manchester: Manchester University Press, 1996) at 56.

68 Savings and Restructuring Act, supra note 49.

69 See Pembroke Civic Hospital v. Ontario Health Services Restructuring Commission, [1997] O.J. No. 3142 (Gen. Div.) (QL); and Wellesley Central Hospital v. Ontario Health Services Restructuring Commission, [1997] O.J. No. 3645 (Gen. Div.) (QL).

Supra note 50 (reduction from 129 to 66 boards). See also An Act to Amend the Schools Act, S.N.B. 1996, c. 16; and Education Act, S.N.B. 1997, c. E-1.12 (eliminates all school boards in favour of parents advisory committees); Education Act, S.N.S. 1995-96, c. 1 (22 school boards restructured into 6 regional boards and 1 province-wide francophone board); An Act to Amend the Schools Act, S.P.E.I. 1994, c. 56 and Reg. EC 355/94 (5 boards restructured to two English language and one French language boards); and School Amendment Act, S.A. 1993, c. 24, s. 21 adding a new s. 208 "Establishment and Dissolution of Regional Divisions" (amalgamations were encouraged with the result that 181 boards have been reduced to 62 ).

$7 \quad$ See Exxon Corp. v. Heinze, 792 F. Supp. 72 at 75 (D. Alaska 1992); and Lucas v. Mercantile-Safe Deposit and Trust Co., 350 A. 2d 156 at 162, quoting Final Accounting in the Estate of A.B., 1 Tucker 247 at 249 (NY Surr. 1866) "No man's life, liberty or property are safe while the Legislature is in session." 